\title{
Logistics of information in intermodal transport
}

\author{
Cezary Mańkowski ${ }^{1, *}$ and Dariusz Weiland ${ }^{1}$, \\ ${ }^{1}$ Department of Logistics, Faculty of Economics, University of Gdansk, Poland
}

\begin{abstract}
The contemporary economy is characterised by a high degree of reliance on modern technologies and information systems. Modern technologies have become a source of innovativeness and a tool for building competitive advantage across all sectors of the market, including transportation. Such technologies as telematics, RFID and GPS/GPRS have contributed to the development of transport systems. Information logistics is crucial in order for the modern technologies to be utilised effectively in transportation. This necessity is driven by the fact that information is a type of resource and hence requieres adequate logistics. The same applies to intermodal transport, where it is vital to manage the stores of information appropriately and efficiently through well organised logistics. This article discusses logistics of information as one of the key auxiliaries to intermodal transport. It also outlines an innovative approach to information as viewed from the perspective of domestic railway companies, which may benefit from implementing information logistics in order to utilise such assets as railway infrastructure, supply trains, train stations, sidetracks and ground adjacent to railtracks. This, in turn, will allow them to transition from being traditional transport suppliers to the rank of logistics integrators responsible for handling intermodal transport. The authors elaborate on the possible functional mechanisms of an intermodal transport market whose management and supervision is assumed by a domestic railway service supplier, thereby becoming an integrator of logistics for intermodal transport whose operating draws on information flows between operators working in different sectors of transport.
\end{abstract}

\section{Inntroduction}

The contemporary economy forces businesses into searching for new, often innovative and above all economically more viable theories and practices of organizing logistics. These trends would certainly not have emerged had it not been for the development of the theory of logistics as well as the contemporary IT systems. It was precisely the synthesis of logistics and IT tools that allowed companies to further tailor their products and services to customer needs, thus building a competitive advantage [1]. For all these decision processes to occur, however, it is crucial that information resources be utilized adequately. What characterizes the type of information that companies use these days is the necessity for it to be handled by means of information and informational systems, which lie at the core of the system of logistics. Both decision-making processes and the constant evolution of the logistics of material assets have been and will continue to be a direct result of the changes in systems of information delivery [2]. The advancement of computer systems and networks has created a specific environment for the growth of information logistics across all sectors of trade and economy. The expansion of information logistics, in turn, created fertile ground for the emergence of ideas, conceptions and utilizations of logistics on a heretofore unprecedented, global scale, a framework for handling economy-related processes within the 5 primary purposes of logistics (5R) - to supply the adequate resource, to an adequate place, at an adequate time, in an adequate amount and at an adequate cost [3].

The transport market has also used the implications of logistics for the development for IT tools. Transportation businesses are now increasingly taking an advantage of such systems as telematics, RFID, GPS and GPRS. Despite the importance of these, it is information logistics that is most crucial for the effective utilization of modern IT tools. The ideas and conceptions created by logisticians have been a major contributor in implementing IT tools in transport and within logistics in general. While these tools do play a vital role in transportation by car and by air, the theories founded within these sectors are being increasingly employed in maritime and railway transport.

It is important, however, to create new implementations for IT tools and logistics especially in the domain of the development of intermodal transport. The purpose of this article is to delineate an outline of how the already existing IT tools may be used for the growth of the branches of intermodal transport.

\section{Information as a resource in logistics}

Regardless of which sector of the economy a given business is operating in, it necessarily produces, stores

\footnotetext{
* Corresponding author's: Cezary Mańkowski - ekocm@ug.edu.pl ; Dariusz Weiland - d.weiland@ug.edu.pl
} 
and utilizes information. In general terms, information can be not only produced, stored and utilized (for example in the decision making-processes), but also sold, which qualifies it as a full-fledged resource. Information is of particular importance when multiple businesses cooperate with one another in order to provide satisfaction to the target customer. In the process, information becomes a substrate for providing added value for the customer and building a competitive advantage. However, the idiosyncratic properties of information set it apart from other resources in logistics. These include [4]:

- the inexhaustibility of information and the possibility of processing it without causing any depletion whatsoever,

- substitutionality,

- complementarity,

- the objectivism of information,

- the virtual nature of information,

- the synergistic nature of information,

- diversity,

- its unlimited capacity to be multiplied and moved in time and space,

- the subjectivity of assessments,

One of the most prominent features differentiating information from other resources is that it does not get depleted during its processing or utilization in the chain of the production processes, one of which being the decision-making procedures. The implication of this fact is that multiple agents may use information simultaneously without any necessity to restore it. The inexhaustibility, however, ought not to be confused with obsolescence and outdatedness of information, since in today's world the lifespan of information is reduced to a minimum.

What also sets information apart from other resources is its virtual nature, which enables it not to be permanently attached to any data carrier. The same piece of information may be stored on multiple drives without any detrimental effects on its value to the recipient. This virtuality is closely related to information's capacity to be multiplied ad infinitum across both space and time. It can be transferred from one data carrier to another and between users no matter how far apart they are.

Aside from the above-mentioned features, information is also characterized by a complex of four properties designated as $4 \mathrm{~V}$, which properties have been heretofore primarily applied only to big data [5]:

volume - great amounts of information,

velocity - great variability of information,

variety - great variety of information,

value - validation of information,

Regardless of their intentions, all companies are increasingly encountering big data in reference to large stores of data and information, which compels them to seek out and create new IT systems that would allow them to purify information off its many irrational elements in accordance with the goals of logistics. These systems are being designed to also support the decisionmaking processes, discover new interconnections and relations, and to optimize processes. At the core of logistics lie the functions that it performs: servicing, processing and integrating. It must be observed, however, that logistics is never the only process in a system, rather, it serves as an auxiliary to the primary process.

Providing logistical support for this process is realized via a series of sequentially arranged activities, whose purpose is to realize the great 5 objectives of logistics (5R). Each of these activities, in turn, is accompanied by an appropriate logistical process. Moreover, in accordance with the integrational function of logistics, all the individual sub-processes that the logistical process consists of need to come together into an integrated unit of subcomponents in relation to the primary process. Successful realization of any traderelated process depends on a well-coordinated functioning of the components of the logistical support for said process [3].

\section{The logistics of information as a component of the system of logistical support for intermodal transport}

Intermodal transport may be defined as an unobstructed movement of payloads via more than one means of transport, with a caveat that said payload is seen a single unit of transportation; during trans-shipment, what is handled is a loading unit (such as a container) rather than goods themselves (the contents of the container) [6]. What characterizes and differentiates intermodal transport from other means of transport is its relative level of safety, its capacity to meet the deadlines and optimization of costs [7]. Other definitions [8,9,10] emphasize the fact that there is only transit agreement meaning that the responsibility for the entire length of transportation falls on one transport service supplier - or that there is no need to use the services of more than one operator, although in practice it appears more reasonable to arrange a close cooperation and integration between several operators rather than to employ of a cohort of means of transport managed by a single company.

The development of this branch of transport is unfortunately severely restricted mainly due to a lack of road, tool and information infrastructure. There still are not enough pre-loading terminals in Europe, and those that do exist have a low functioning capacity [11]. Another important problem is a lack of unified standards for the exchange of information between transport providers and the customers, which should be uniform on an international level, while the software used by companies ought to be made compatible with information and informatics systems and in the networks that land and sea-land transport chains use. One faces similar obstacles in the relations between transport operators and customers, whereby the latter often receives an insufficient amount of information from the former.

Intermodal transport is characterized by an immense flow and importance of information. Information is crucial if this type of transportation is to operate 
correctly, which is a consequence of two factors: the necessity to acquire and process information for the purposes of a particular process, and its importance in communication. Said communication obtains not only within a company responsible for given transportation, but also between companies and their customers or other participants of cooperation. Hence, providing logistical support of intermodal transport consists primarily in acquiring, processing and transferring the information that is relevant at every stage of the process; further, it consists in updating said information along the way and organizing an undisturbed flow of it both with a company and between the company and its surroundings [12].

Information is delivered to businesses via IT systems, which makes said systems a key component of the system of logistical support. It is an information system that is responsible for acquiring and processing data for user-defined purposes. These data are obtained from within the company and its surroundings. Once data is introduced into the system, it becomes information. Another function of IT systems is that they mediate communication between different company departments, between customers and contractors. If well thought-out, thoroughly planned, built in line with the objectives of logistics and equipped with the indispensable infrastructure, an IT system should be capable of delivering information to all workplaces along every level of organizational hierarchy without neglecting any of the purposes of logistics (5R) in reference to the information stores. Unfortunately, intermodal transport poses a big challenge for IT and logistics sectors, as it is necessary to define and construct a system that would offer multiple points of data acquisition, as well as service multiple information recipients simultaneously. The inevitable consequence of this is reduced output of the traditional data bases, which has been incentivizing attempts at creating NoSQL data bases and data bases with blockchain technology as their foundation. Furthermore, the unique properties of intermodal transport make it necessary to integrate at least two different means of transport, thus necessitating implementation of such systems enable multiple businesses to establish integrated and coherent channels of communication and means of exchanging data and information. In intermodal transport, data are downloaded primarily through RFID devices, telematics tools, GPS in transport chains, via transport-monitoring devices, and other GSM equipment of short- and longranges. These data are produced en masse and go out of date rapidly due to incessant movement, which is why contemporary information was compared to big data in the previous part of this article. Another challenge of equal importance is how to provide sufficient securing of the information system from unauthorized use of its data via encryption techniques based on complex algorithms, which are necessary because these data constitute private business information. The threats that these systems most frequently encounter can be subdivided into the following categories [13]:

- obtaining access to the date being transmitted via the internet or stored on servers by unauthorized agents;
- obtaining unauthorized access to other resources, such the computational power;

- loss of data due to malware or as a result of cyberattack,

- falsification of data,

- attacks that make a machine or network resource unavailable to its intended, authorized users (Denial of Service).

Whether intermodal transport is successful within the coming years will hinge on the rate at which these obstacles and limitations are successfully diffused through implementation of innovative IT solutions that would integrate various systems of communication between different links along the chain of intermodal transport. The information regarding documents, storage units, trans-shipment equipment, transport chains, infrastructure, prices, etc., is expected to be stored in one place.

\section{Railway transport companies integrators in intermodal transport}

Railway transport companies play a dominant role in the majority of intermodal transport systems. These service providers have at their disposal their own fleets and a fully-operational infrastructure, and they are often owners or managers of trans-shipment terminals [14]. What also distinguishes railway transport companies is possession of multiple other assets, which often remain underutilized such as inactive sidetracks and the land adjacent to the rail tracks, which, in the future, may be used to build a competitive advantage within the intermodal transport sector and facilitate development of terminal infrastructure. What follows is a two-section outline of a model of organizing intermodal transport. The first section discusses how railway transport providers may start serving a integration role in intermodal transport, while the second section elaborates on possible routes of implementation and utilization of innovative IT systems that would enable unobstructed flow of information and acquisition of new customers.

As previously discussed, one of the key functions of logistics is integration, and for integration to be appropriately implement, the role of the rail transport provider needs to be changed from that of a transport company to one of a 5PL logistics operator (5 logistics partner). A logistics operator (5PL) integrates multiple components within a single information system, including recipients, users, contractors and the existing infrastructure in order to maximize target customer satisfaction and optimize the costs [15]. At the same time, the information system of the operator creates a digital equivalent of the logistical processes that occur in intermodal transport [16] (Figure 1). 


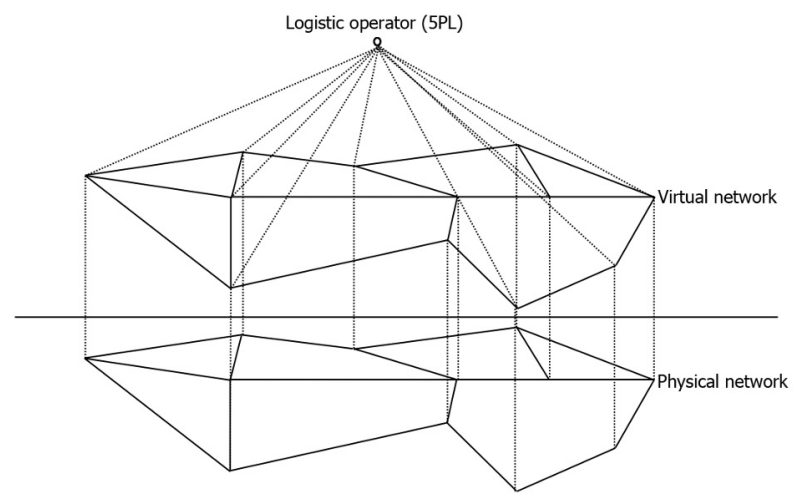

Fig. 1. Virtual reflection of the logistic physical network Source : Own elaboration

Creating these digital records consists in defining a virtual network that would mirror the on-the-ground network, thus allowing for an effective management of all resources along the entire system and exerting adequate control of individual operations, including those relating to trans-shipment and intermodal terminals. This makes the role of a logistics operator equivalent to that of an integrator of information flow along the entire chain of transport. Supply Chain Control Tower is a concept that translates this idea into the realm of intermodal transport most accurately. However, the tasks of the Control Tower do not end here, as it should also serve as a means of monitoring the centers of costs in a company and organizing the information flow and the entire process of transport from the point at which the arises a need of transportation up until the moment of its conclusion at the doorstep of the target customer.

Supply Chain Control Tower is defined in a variety of ways across the literature. According to one of the broadest and most multi-faceted definitions, SCCT is a centralized system of the required technological level that aims at organizing component processes and acquiring and analyzing data flowing from the chain of delivery in order to provide greater transparency [17, 18]. Such a holistic, real-time perspective on all of the subcomponents of intermodal transport may allow operators of railway logistics sufficient space to make appropriate short- and long-term decisions that would be in accordance with the objectives of the operator as well as the goals of the entire process (Figure 2).

The Control Tower is responsible for monitoring, controlling and support intermodal transport in real time on three levels [19]:

- strategic - it mediates control over the entire on-theground network and its virtual counterpart,

- tactical - it is a tool used for planning routes and adjusting business decision to market demands, all the time taking into account the costs of the whole process,

- operational - it comprises a variety of activities and decisions connected with transport management and monitoring, as well as the area of reacting to the arising obstacles.

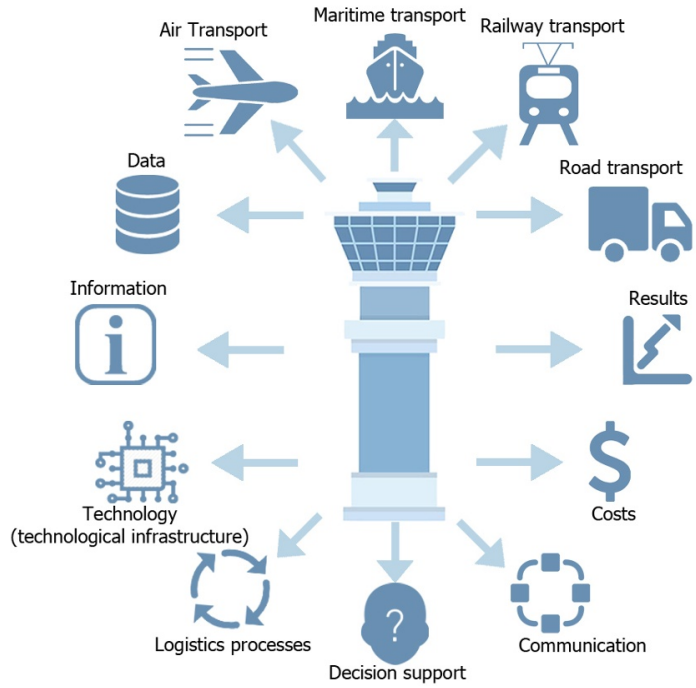

Fig. 2. Control tower for intermodal transport Source : Own elaboration

Considering the unique characteristics of intermodal transport, it is impossible to directly incorporate the already existing SCCT solutions; what is necessary instead is to create a system based on this framework from ground up and make all the adjustments that will enable it to meet current market demands.

Creating SSCT and position 5 logistics operator by the railway transport provider ought to happen alongside making an information system designed specifically for intermodal transport (the clients and the cooperators within the network of delivery service providers). The other component of the idea presented herein is building a market of intermodal transport that would operate in a similar fashion to other sectors of transport pertaining to transportation via car. The implementation of these solutions would, however, require investments connected with the already owned assets, expanding intermodal terminals, creating new terminals in the vicinity of railway stations, sidetracks and areas of land owned by railway transport providers, and all this with the use of such trans-shipment and transportation technologies as Cargobeamer, Modalohr, Flexiwaggon, and Rollende landstrasse.

An appropriate synthesis of these two segments will allow for a harmonious and uninterrupted organization of a multi-branch transport. A single company would be capable of monitoring the entire process of intermodal transport, thus increasing the overall importance of railway transportation. By investigation the transport market, the clients would be able to localize vacant train cars waiting to transport delivery units and then move their products to that destination. The entire flow of delivery units would be managed by a single company, which would contribute a greater synchronization between different means of transport. 


\section{Summary and directions for future research}

Creating position 5 logistics partner based on the SCCS framework makes it possible to react swiftly to the everchanging management conditions, market demands and the difficulties experienced by deliverers operating within a single system. The development of data transfer networks aids and facilitates the process of professionalizing activities within logistics with the use of the already existing logistics operators. The idea discussed in this article suggests creating and utilizing a virtual network of data and information flow between all of the participants and agents of intermodal transport along with creating a platform in the form of an electronic market for intermodal transport. For the degree of control that such a system would guarantee to be fully realized, appropriate applications and support by information acquired from the market would be necessary. As a consequence, the process of managing the logistics would be faster even in case of intermodal transport.

The future directions for research in this area should focus on a model-based discussion of the leading idea and on creating a realizability study together with a SWOT analysis.

\section{References}

1. D. Weiland, Studia Ekonomiczne : zeszyty naukowe Uniwersytetu Ekonomicznego w Katowicach. 306, 97-110 (2016)

2. M. Chaberek, Informatyczne narzędzia procesów logistycznych, Eds. M. Chaberek, A. Jezierski, pp. 13-23, (2010)

3. M. Chaberek, Makro- i mikroekonomiczne aspekty wsparcia logistycznego, p. 15. (2002)

4. E. Skrzypek, G. Annales Universitatis Mariae CurieSkłodowska, Sectio H, Oeconomia 39 (2005)

5. D. Weiland, Research Journal of the University of Gdańsk. Transport Economics and Logistics (Modelling of Logistics Processes and Systems) 71. 179-190 (2017)

6. J. Neider, D. Marciniak-Neider., Transport intermodalny, (1997)

7. H. Zielaskiewicz, Transport intermodalny na rynku ustug przewozowych. (2010)
8. H. Adelsberger, Intermodal terminals in an integrated transport system of the Baltic Sea region, (2012)

9. K. Liljestrand, Intermodal transportation from a haulier's perspective. An analysis on how to increase the usage of intermodal road-rail transportation for hauliers in Sweden. Chalmers University of Technology, No. 087 (2010)

10. M. Ruesch, A. Heiko, R. Karrer, Integrated Services in the Intermodal Chain (ISIC). Final Report Task D: “Improving Quality of Intermodal Terminals" (2005)

11. M. Zalewska-Turzyńska, Technologie informacyjno komunikacyjne $\mathrm{W}$ transporcie intermodalnym, Infrastruktura transportu dla rodzowju regionów. Zagadnienia teoretyczne i pragmatyczne, (2014)

12. G. Karwacka, Monitoring informatycznych komponentów systemu logistycznego przedsiębiorstwa. Informatyczne narzędzia procesów logistycznych, Eds. M. Chaberek, A. Jezierski, pp. 77-85 (2010)

13. S. Sokół, Zagrożenia w sieci. Available from http://home.agh.edu.pl/ szymon/artykuly/legionowo. html [Accessed 2 September 2018]

14. J. Stokołosa, Š. Liščak, M. Jaśkiewicz, K. Ludwinek, Systemy transportu intermodalnego - kierunki rozwoju w świetle europejskich doświadczeń. Logistyka No. 6 (2014)

15. Fifth party logistics model (5PL), Logistics Glossary. Available from http://www.logisticsglossary.com/term/5pl/

16.Z. Bentyn, E-logistyka narzędziem rozwoju globalnych sieci dostaw. Gospodarka materiałowa $i$ logistyka No.5 (2015)

17. B. Benz, Supply Chain Control Tower help organizations respond to new pressures, Supply Chain Management Review 18(4), pp. 34-39 (2014)

18. A. Trzuskawska-Grzesińska, Control towers in supply chain management - past and future, Journal of Economics \& Management, 27, pp. 114-133, (2017)

19. M. Makar, M. Karkula, Monitorowanie i kontrola łańcucha dostaw: koncepcja Supply Chain Control Tower i jej zastosowanie w przedsiębiorstwie handlu detalicznego. Prace Naukowe Politechniki Warszawskiej, Transport, No. 120 (2018) 